\title{
Pittosporum halophilum Rock (Pittosporaceae: Apiales): Rediscovery, Taxonomic Assessment, and Conservation Status of a Critically Endangered Endemic Species from Moloka'i, Hawaiian Islands ${ }^{1}$
}

\author{
Kenneth R. Wood ${ }^{2,4}$ and Michael Kiehn $n^{2,3}$
}

\begin{abstract}
Pittosporum halophilum Rock originally was known only from the type collections made in 1910 and 1911 along the windward sea cliffs of Moloka'i. In the most recent revision of Hawaiian Pittosporum it was treated as synonymous with the more common species P. confertiflorum A. Gray. Since 1994, several plants fitting the circumscription of $P$. halophilum have been discovered near the type locality. Careful studies of these individuals and of plants cultivated from their seeds clearly revealed that they are not only characterized by salt tolerance, but differ from P. confertiflorum also in several other characters (i.e., a small, shrubby habit; smaller leaves with cuneate bases and unique tan to golden yellow wooly dense tomentum on abaxial leaf surfaces; shorter petioles; subcuboid to ovoid capsules; and, in most individuals, functionally unisexual flowers). Based on these substantial differences we conclude that P. halophilum merits recognition on species level. In this paper we give a detailed description of P. balophilum including remarks on its conservation status.
\end{abstract}

The genus Pittosporum is the largest member of the family Pittosporaceae, with 100 or more species. Its members are readily identified by the unilocular fruits with bright orange, red, or brown seeds immersed in a sticky resin (Cayzer et al. 2000). The Hawaiian species of the genus form a strongly supported monophyletic clade in rDNA internal transcribed spacer sequence (ITS) studies (Gemmill et al. 2002), suggesting a single colonization event followed by phyletic radiations. The monophyly of the Hawaiian taxa is further supported by morphological features such as increased seed and capsule size and

\footnotetext{
${ }^{1}$ Manuscript accepted 20 January 2011.

2 National Tropical Botanical Garden, 3530 Papālina Road, Kalāheo, Hawai'i 96741.

${ }^{3}$ Botanical Garden, University of Vienna, Rennweg 14, 1030 Vienna, Austria.

${ }^{4}$ Corresponding author (e-mail: kwood@ntbg.org).
}

Pacific Science (2011), vol. 65, no. 4:465-476

doi: $10.2984 / 65.4 .465$

(C) 2011 by University of Hawai'i Press

All rights reserved capsule woodiness as compared with nonHawaiian taxa (Carlquist 1966, 1974, Gemmill et al. 2002). Furthermore, ITS analyses indicate that the Hawaiian taxa share a common ancestor with the Fijian $P$. rbytidocarpum A. Gray and the Tongan P. yunckeri A. C. Sm. (Gemmill et al. 2002, Chandler et al. 2007). These results support the hypothesis of Fosberg (1948) and Haas (1977) that the Hawaiian Pittosporum lineage is the result of a single long-distance dispersal event (via birds) from the South Pacific. Including P. balophilum Rock, the Hawaiian Islands now harbor 11 species of Pittosporum (Rock 1911, Wagner and Herbst 1999).

Seven Hawaiian Pittosporum species represent single-island endemics, and the remaining four species occur on at least two islands. Eight species are considered rare and/or endangered by field botanists (e.g., Wagner et al. 1999), namely $P$. argentifolium Sherff, $P$. flocculosum (Hillebr.) Sherff, P. gayanum Rock, P. halophilum, P. hawaiiense Hillebr., P. kauaiense Hillebr., P. napaliense Sherff, and P. terminalioides Planch. ex A. Gray. Recently $P$. napaliense was listed as federally endangered (U.S. Fish and Wildlife Service 2010). 
Historical and Taxonomic Notes on Pittosporum halophilum

Pittosporum halophilum was originally described by Joseph Francis Rock from collections made in 1910 and 1911 on Moloka'i, Hawaiian Islands (Rock 1911, Sherff 1942, Haas 1977). Some confusion about the name of the taxon was created by an orthographic error made during the original publication whereby the name was mistakenly altered to $P$. balophylum. This was later corrected by Sherff (1941) to the current spelling, which appears in Rock's own handwriting on the type collection at BISH (Figure 1). This correction of the spelling was accepted because "balophylum" is not correctly formed Latin. In such a case, the International Code of Botanical Nomenclature (ICBN) allows a change to the correct Latin term. Rock (1911) remarked that "the name $P$. litorale was used at first in the manuscript, but having been anticipated for a Philippine species by Merrill, the Greek name $[P$. halophilum] was substituted." The type specimens of $P$. balophilum do not show important morphological characters (e.g., they do not include capsules). Haas (1977) considered P. halophilum to be a form of $P$. terminalioides (i.e., $P$. terminalioides f. balophilum), yet trees of $P$. terminalioides grow 4-6 $\mathrm{m}$ tall in comparison to $P$. halophilum, which even in cultivation remains shrubby and only $0.4-1.75 \mathrm{~m}$ tall. Pittosporum halophilum also has smaller leaves than P. terminalioides, and they are not as densely clustered toward the ends of the branches as is typical for $P$. terminalioides. In addition, the capsules of $P$. halophilum (now known from recent collections) are not strongly compressed and lack the smooth surface characteristic of $P$. terminalioides. Having only the type collections to refer to, the treatment of Hawaiian Pittosporum in the Manual of the Flowering Plants of Hawai'i (Wagner et al. 1990) considered the material of P. halophilum to fall within the circumscription of $P$. confertiflorum and, therefore, did not recognize it as a distinct species or form. In the supplement to the Manual of the Flowering Plants of Hawai' $i$, Wagner and Herbst (1999:1887) stated (with regard to $P$. halophilum) "recent collections have shown this coastal taxon to be a distinct species" but included no further comments, no citations of collections in question, no taxonomic description, and no key couplet to separate $P$. halophilum from $P$. confertiflorum.

The fate of Pittosporum halophilum has been of keen interest to botanists working on the Hawaiian flora because it represents the only Hawaiian member of the genus that grows within the salt spray zone (Rock 1911, Wood 2001). Although a fair amount of suitable habitat exists along the northern sea cliffs and islets of Moloka'i, P. halophilum remained elusive for over 80 yr. In 1994, however, two plants that fit Rock's description for P. halophilum, especially regarding salt spray tolerance, shrubby habit, and tan to golden yellow wooly tomentum, were discovered on the western vertical walls of Huelo Islet, Moloka' $i$, within sight of the type locality. The two plants had pistillate flowers, and seeds from one plant were collected in 1994 and 1999 (Table 1), before both shrubs succumbed to a landslide. Currently, no individuals of $P$. balophilum are known from Huelo (Wood and LeGrande 2002); however, numerous individuals grown from the seeds collected on Huelo are being cultivated at the National Tropical Botanical Garden (NTBG) and are good candidates for reintroduction to the islet.

Ongoing biotic inventories by K.R.W. around the northern coast of Moloka'i have subsequently revealed the existence of a small number of additional plants with the features characteristic for $P$. balophilum within a $3 \mathrm{~km}^{2}$ area extending from the islets of Mōkapu and 'Ōkala to the coastal Kūka'iwa'a Peninsula of Moloka'i (see Figure 2). A total of 20 shrubs has been documented so far. As part of ongoing conservation efforts, Kalaupapa National Historical Park (KNHP), Moloka'i, together with the NTBG, Kalāheo, Kaua'i, and the Offshore Islet Restoration Committee (OIRC) of Hawai'i have been collecting seeds and cuttings from most of these plants and have cultivated approximately 150 individuals, several of which are copiously producing seeds. However, 12 of the originally documented plants have meanwhile succumbed to either severe erosion or landslides and/or extended dry periods (Table 1). 


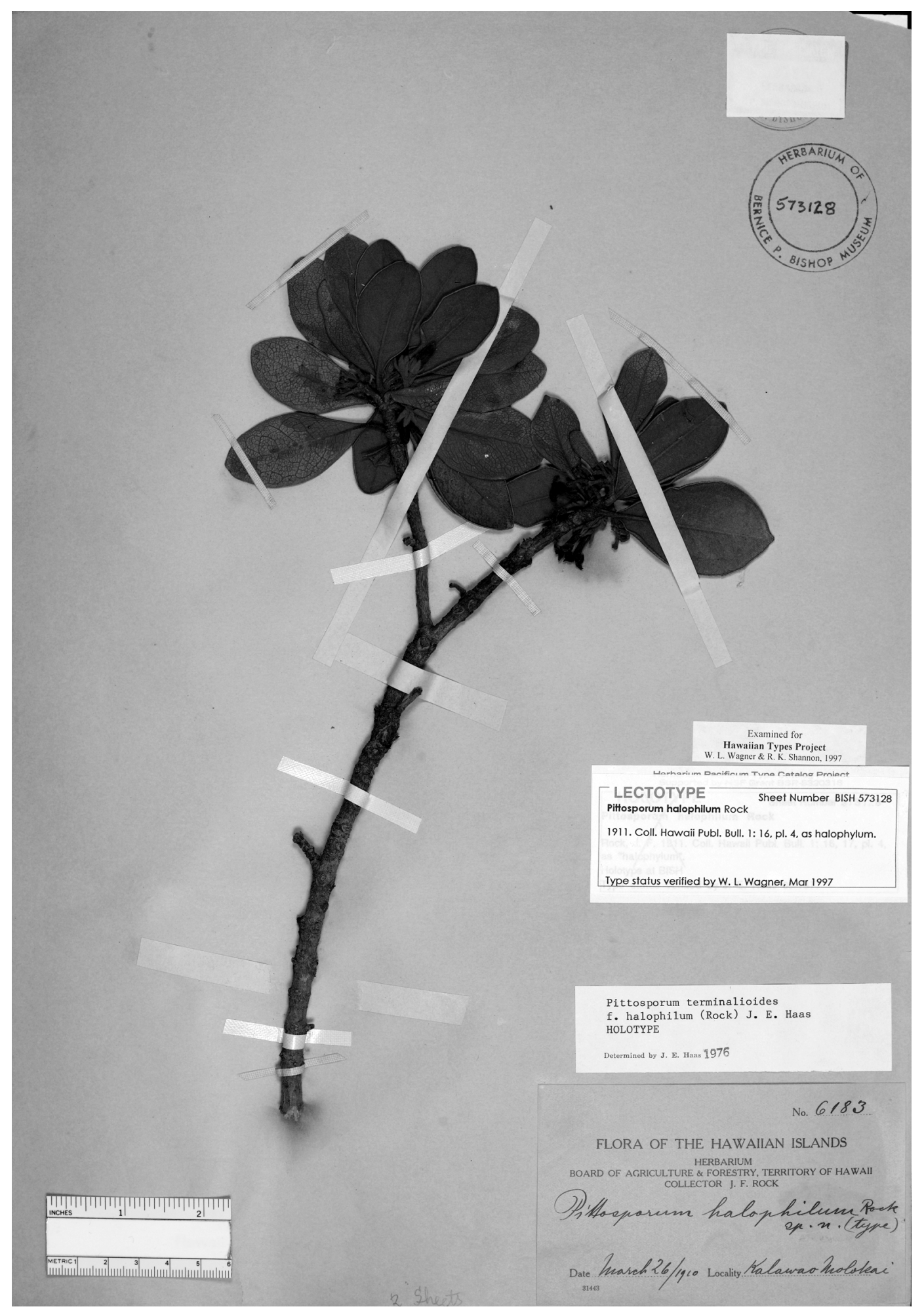

Figure 1. Lectotype specimen of Pittosporum halophilum; Rock [๘ Nevin] 6183, BISH-573128. 
TABLE 1

Record of Conservation Collections and In Situ Status of Pittosporum halophilum

\begin{tabular}{|c|c|c|c|}
\hline Plant ID & Sex & $\begin{array}{c}\text { Conservation Accession Nos. with } \\
\text { Material/Year/Collector ID }\end{array}$ & $\begin{array}{l}\text { In Situ Status, Year of Last } \\
\text { Observation, and Comments }\end{array}$ \\
\hline \multirow[t]{2}{*}{ Huelo \#1 } & Pistillate & NTBG 940355 (seed/1994/Wood 3839) & Dead (2001): landslide \\
\hline & Pistillate & NTBG 990860 (seed/1999/Wood 8027) & Dead (2001): landslide \\
\hline Huelo \#2 & Pistillate & None & Dead (2002): landslide \\
\hline Mōkapu \#1SE & Pistillate & LYON 5977 (seed/2009/Oppenheimer20090403) & Living (2009) \\
\hline Mōkapu \#2SE & Staminate & None & Dead (2001): landslide \\
\hline \multirow[t]{2}{*}{ Mōkapu \#2NE } & Pistillate & NTBG 010745 (seed/2001/Wood 9209) & Dead (2006) \\
\hline & Pistillate & KNHP 10403kw (seed/2003/Wood 10403) & Dead (2006) \\
\hline Mōkapu \#3NE & Pistillate & NTBG $010746($ seed/2001/Wood 9210) & Dead (2006) \\
\hline \multirow[t]{2}{*}{ Mōkapu \#4NE } & Pistillate & KNHP 10404kw (seed/2003/Wood 10404) & Dead (2008) \\
\hline & Pistillate & NTBG 060029 (seed/2006/Wood 11713) & Dead (2008) \\
\hline \multirow{5}{*}{ Mōkapu \#5NE } & Pistillate & NTBG 000206 (seed/2000/Perlman 16995) & Living (2006) \\
\hline & Pistillate & KNHP 10228kw (seed/2003/Wood 10228) & Living (2006) \\
\hline & Pistillate & KNHP $10402 \mathrm{kw}$ (seed/2003/Wood 10402) & Living (2006) \\
\hline & Pistillate & NTBG 060030 (seed/2006/Wood 11714) & Living (2006) \\
\hline & Pistillate & NTBG 061292 (seed/2006/Wood 12201) & Living (2006) \\
\hline \multirow[t]{3}{*}{ Mōkapu \#6NE } & Pistillate & KNHP 10401kw (seed/2003/Wood 10401) & Living (2008) \\
\hline & Pistillate & NTBG 060031 (seed/2006/Wood 11715) & Living (2008) \\
\hline & & NTBG 080948 (seed/2008/Wood 13366) & Living (2008) \\
\hline \multirow[t]{2}{*}{ Mōkapu \#7NE } & Pistillate & NTBG 000207 (seed/2000/Perlman 16996) & Living (2006) \\
\hline & Pistillate & NTBG 060032 (seed/2006/Wood 11716) & Living (2006) \\
\hline Mōkapu \#8NE & Unknown & None & Dead (2003) \\
\hline Mōkapu \#9NE & Pistillate & None & Dead (2006) \\
\hline Mōkapu \#10NE & Staminate & NTBG 010098 (pollen/2001/Wood 8871) & Dead (2003) \\
\hline \multirow[t]{2}{*}{ Mōkapu \#kw010 } & Pistillate & NTBG 010747 (seed/2001/Wood 9211) & Living (2006) \\
\hline & Pistillate & NTBG 061291 (seed/2006/Wood 12200) & Living (2006) \\
\hline Mōkapu \#12NE & Staminate & None & Dead (2002): landslide \\
\hline Mōkapu \#13NE & Pistillate & NTBG 000280 (seed/2000/Wood 8303) & Dead (2002): landslide \\
\hline Mōkapu \#14NE & Staminate & None & Dead (2002): landslide \\
\hline \multirow[t]{3}{*}{ 'Ōkala \#1 } & Pistillate & NTBG 020222 (seed/2002/Wood 9829) & Living (2006) \\
\hline & Pistillate & KNHP 10198kw (seed/2003/Wood 10198) & Living (2006) \\
\hline & Pistillate & NTBG 060045 (seed/2006/Wood 11737) & Living (2006) \\
\hline \multirow[t]{2}{*}{ ‘Ōkala \#2 } & Staminate & KNHP 10199kw (cutting/2003/Wood 10199) & Living (2006) \\
\hline & Staminate & NTBG 060046 (cuttings/2006/Wood 11738) & Living (2006) \\
\hline \multirow[t]{2}{*}{ Kūka'iwa'a \#1 } & Pistillate & NTBG 020221 (seed/2002/Wood 9821) & Living (2006) \\
\hline & Pistillate & KNHP 1158gh (seed/2006/Hughes 1158) & Living (2006) \\
\hline
\end{tabular}

Note: Living collections are being curated at the National Tropical Botanical Garden (NTBG), the Kalaupapa National Historical Park (KNHP), and the Lyon Arboretum (LYON).

\section{MATERIALS AND METHODS}

Descriptions and observations reported here are based on wild source individuals from Moloka' $i$ and adjacent islets studied between 1994 and the present, on cultivated individuals of Pittosporum halophilum grown and curated at the NTBG, on ethanol-preserved material, and on herbarium vouchers. Measurements for the species description were taken from herbarium specimens housed at the PTBG her- barium, Kalāheo, Hawai'i, in addition to the type collections at BISH herbarium, Honolulu, Hawai'i. Specimens from both herbaria were used for comparative studies between $P$. halophilum and other Hawaiian Pittosporum. Chromosome data were obtained using the techniques described in Kiehn (2005), from apex tissue of a plant cultivated at the NTBG (acc. no. 060031-003; voucher Kiehn MK090115-1/4, WU) grown from wild-collected seed of Wood 11715 from Mōkapu, Moloka 'i. 


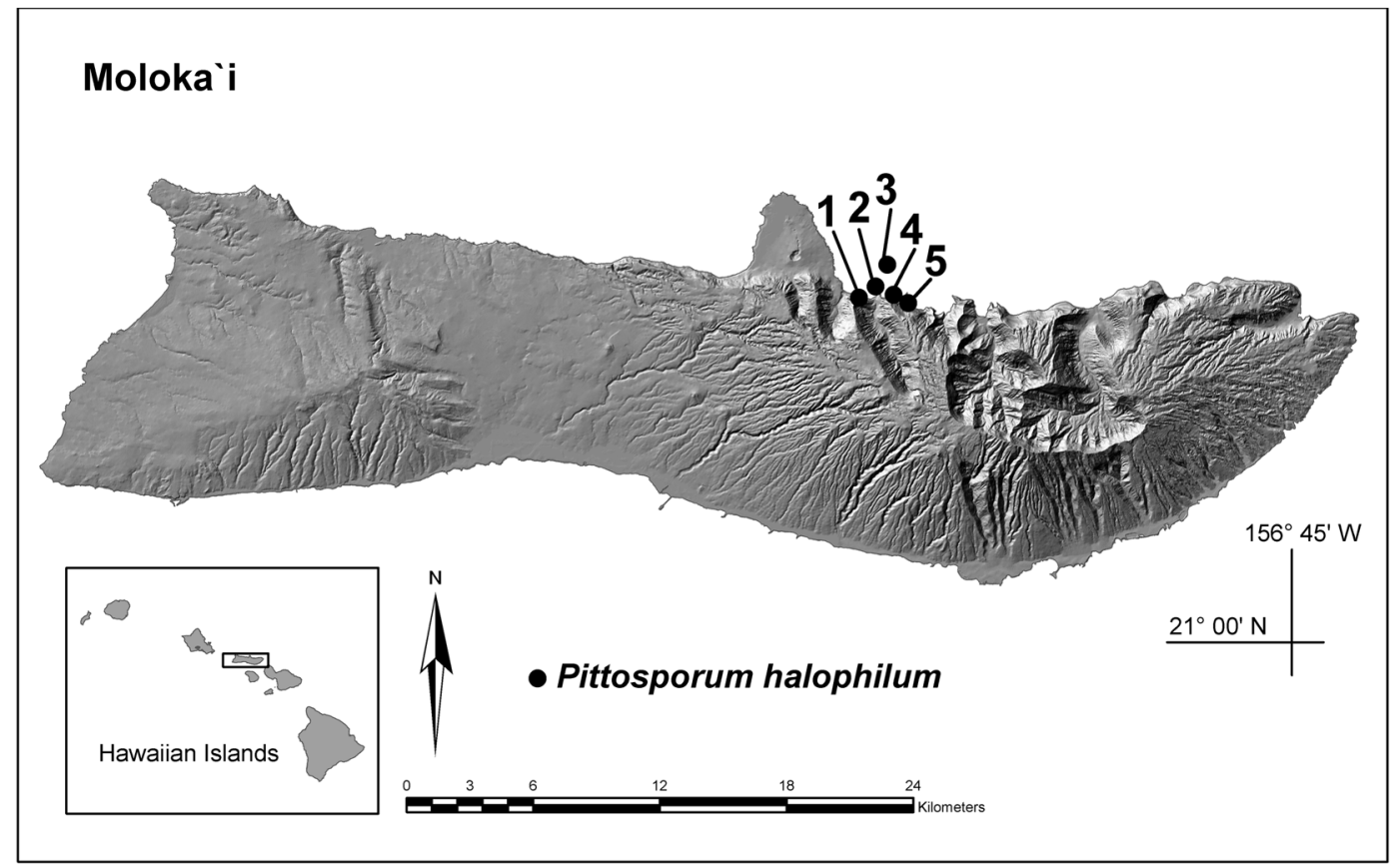

Figure 2. Distribution of Pittosporum halophilum on the windward side of Moloka'i. Sites, abundance, year of discovery, and representative voucher: 1, Kalawao headland, one plant documented in 1910 (Rock \& Nevin 6183), and no plants currently known (2011); 2, 'Ōkala Islet, two plants documented in 2002 (Wood \& LeGrande 9829), two plants still currently known; 3, Mōkapu Islet, 15 plants documented in 2000 (Wood \& Perlman 8298), five plants currently known; 4, Huelo Islet, two plants documented in 1994 (Wood 3839), both destroyed by landslide, no plants currently known; 5, Kūka'iwa'a Peninsula, one plant documented in 2002 (Wood \& LeGrande 9821), one plant still currently known.

\section{RESULTS}

Pittosporum halophilum Rock

Pittosporum halophilum Rock, in Coll. Hawaii Publ. Bull. 1:16, pl. 4, as P. balophylum, 1911; Sherff in Am. J. Bot. 28:18, 1941; Sherff in Field Mus. Nat. Hist. Publ. Bot. Ser. 22:523, 1942; P. terminalioides $\mathrm{f}$. halophilum (Rock) J. E. Haas, Allertonia 1:111-112, 1977.-TYPE: U.S.A., Hawaiian Islands, Moloka'i: [between] Kalawao [and Waikolu, along beach on windward side of island, within spray of the sea], 26 Mar. 1910, Rock [\& Nevin] 6183. Lectotype [BISH-573128]. Isolectotype [BISH573127]. Lectotypified in Sherff, Field Mus. Nat. Hist. Publ. Bot. Ser. 22:524, 1942. Syntype: same locality, 14 August 1911, Nevin $6183 a$ (BISH).
DESCRiption: Small shrubs $0.4-1.75 \mathrm{~m}$ tall, young parts and inflorescences sparsely to densely covered with whitish gray to golden yellow tomentum; branches gray brown, subglabrate; leaves coriaceous, rugose, obovate to oblanceolate, $3.5-7.0 \mathrm{~cm} \times 1-3.3 \mathrm{~cm}$, lateral veins 5-9 pairs, upper surface with prominently impressed veins, tan to golden brown strigose, or with silky white yellow pubescence on young growth, soon glabrate, dark green when fresh, lower surface with slightly raised veins, densely covered with a tan to golden yellow tomentum, margins entire, slightly to strongly revolute, apex obtuse to rounded or retuse, base cuneate, petioles $0.2-1.2 \mathrm{~cm}$ long; flowers mostly functionally unisexual (very rarely hermaphroditic; rudimentary ovaries present in staminate flowers), 5-10 flowers in terminal, axillary or cauline, 
simple corymbose inflorescences, fragrant, peduncles 5-15 $\mathrm{mm}$ long, pedicels $4-6 \mathrm{~mm}$ long, bracts subulate to acicular, 2-5 $\mathrm{mm}$ long; calyx cup shaped, sepals distinct, lanceolate, 4-5 mm long, both surfaces densely light yellow to golden lanate, apex acute; petals white to cream colored, 13-15 mm long; filaments of staminate flowers $6-8 \mathrm{~mm}$ long, those of pistillate flowers, when present, 3.5$4.5 \mathrm{~mm}$ long, fertile anthers oblong 2.5-3.0 $\mathrm{mm}$ long, those of pistillate flowers, when present, seemingly sterile, ca. $1.3-1.5 \mathrm{~mm}$ long; ovary hirsute, 2-carpellate; capsules subcuboid to ovoid, \pm compressed, if so then oblong-ovoid, 20-35 mm long, densely tan to golden brown tomentose, apex obtuse to truncate, the persistent style ca. 2-3 mm long, the valves with woody exocarp 3-4 mm thick, coarsely rounded-tuberculate, the troughs between the tubercles broad, smooth, and gently sloping, seed mass filling the capsule volume, ca. 25-50, black, ovoid to irregularly angled and compressed, 5-8 $\mathrm{mm}$ long.

ADDITIONAL SPECIMENS EXAMINED: HAWAI'I: MOLOKA'I: Huelo Islet, $21^{\circ} 10^{\prime}$ $\mathrm{N}, 157^{\circ} 55^{\prime} \mathrm{W}, 60 \mathrm{~m}$ elev., 9 Dec. 1994, Wood 3839 (PтвG), loc. id., 9 Nov. 1999, Wood et al. 8027 (PTBG), 8029 (PTBG); Kūka'iwa'a Peninsula, $21^{\circ} 10^{\prime} \mathrm{N}, 157^{\circ} 55^{\prime} \mathrm{W}, 46 \mathrm{~m}$ elev., 6 Jun 2002, Wood \& LeGrande 9821 (PTBG); Mōkapu Islet, $21^{\circ} 12^{\prime} \mathrm{N}, 157^{\circ} 56^{\prime} \mathrm{W}, 60 \mathrm{~m}$ elev., 8 Mar. 2000, Wood et al. 8298 (PTBG), loc. id., 60 m elev., 8 Mar. 2000, Wood et al. 8302 (PTBG), loc. id., $46 \mathrm{~m}$ elev., 8 Mar. 2000, Wood et al. 8303 (PTBG), loc. id., 8 Mar. 2000, Perlman et al. 16994 (PTBG), loc. id., 8 Mar. 2000, Perlman et al. 16996 (PTBG), loc. id., 24 m elev., 21 Nov. 2001, Wood \& LeGrande 9209 (PTBG), loc. id., 21 Nov. 2001, Wood \& LeGrande 9210 (PTBG), loc. id., 50 m elev., 10 Jan. 2006, Wood \& Espaniola 11713 (PTBG), loc. id., $50 \mathrm{~m}$ elev., 10 Jan. 2006, Wood \& Espaniola 11714 (PTBG); 'Ōkala Islet, $21^{\circ} 11^{\prime} \mathrm{N}, 157^{\circ} 56^{\prime} \mathrm{W}, 21 \mathrm{~m}$ elev., 7 Jun 2002, Wood \& LeGrande 9829 (PTBG). Cultivated specimens: KAUA'I: Kōloa District, Lāwa'i, National Tropical Botanical Garden, cultivated from wild-collected seed of Wood 3839 from Huelo, Moloka'i, NTBG Acc. no. 940355, 31 Mar. 2008, Wood \& DeMotta 12934 (BISH, PTBG); loc. id., cultivated from wild-collected seed of $W_{\text {ood }} 11715$ from
Mōkapu, Moloka‘i, NTBG Acc. no. 060031003, Kiebn MK-090115-1/4 (wU); loc. id., cultivated from wild-collected seed of Wood 9209 from Mōkapu, Moloka'i, NTBG Acc. no. 010745, 3 Apr. 2008, Wood \& DeMotta 12938 (BISH, PTBG, US); loc. id., cultivated from wildcollected seed of Wood 8303 from Mōkapu, Moloka'i, NTBG Acc. no. 000280, 3 Apr. 2008, Wood \& DeMotta 12939 (BISH, PTBG, US).

DisTRIBUTION: Restricted to the northern coast and islets of Moloka'i, just to the east of Kalaupapa. Historically known from Kalawao (1910) and recently documented on Kūka'iwa'a Peninsula and the three islets of Huelo, Mōkapu, and 'Ōkala. No extant individuals are known from Huelo since 2002 (Figure 2).

PHENOLOGY: Flowering: March-July and November-January; fruiting NovemberJune.

CHROMOSOME NUMBER: In the course of ongoing studies of chromosome numbers in Hawaiian Pittosporum (Kiehn 2005; M.K., unpubl.), $2 n=24$ was established as the chromosome number of $P$. halophilum, based on investigations of a plant growing at the nursery of the NTBG (MK-090115-1/4, wU). This number deviates from counts for two unidentified Hawaiian Pittosporum species ( $2 n=$ 34-36 [Kiehn 2005]) but is in accord with counts for six other Hawaiian Pittosporum species (P. glabrum Hook. \& Arnott [Carr 1978], $P$. gayanum [Kiehn 2005], and $P$. hosmeri Rock, $P$. kauaiensis Hillebr., $P$. napaliense, $P$. terminalioides [M.K., unpubl.]). Chromosomes are subtelocentric to telocentric, 6-9 $\mu \mathrm{m}$ long in mitotic (pro)metaphase, and are indistinguishable from those of other Pittosporum species cytologically investigated to date (M.K., unpubl.).

MOlecular studies: Molecular investigations of the nrITS region of Hawaiian members of the genus Pittosporum showed no variability for this genetic marker (Gemmill et al. 2002 [P. balophilum not included in that study]). However, preliminary DNA fingerprinting studies by C. Hogne-Beattie and C. Gemmill (unpubl. data) of ISSRs (intersimple sequence repeats [see RakoczyTrojanskowska 2004 for details]) carried out on Hawaiian members of Pittosporum includ- 
ing $P$. confertiflorum and $P$. balophilum revealed genetic differences. In the course of those studies several individuals of each of those two species were analyzed. According to the results both species seem to be closely related but are separable on the basis of the ISSR loci (C. Hogne-Beattie and C. Gemmill, unpubl. data).

IUCN RED LIST CATEgory: Pittosporum balophilum falls within the Critically Endangered (CR) category, which designates species facing the highest risk of extinction (International Union for Conservation of Nature and Natural Resources 2001; see also www .iucnredlist.org/info/categories_criteria2001). The formal evaluation can be summarized by the following IUCN hierarchical alphanumeric numbering system (International Union for Conservation of Nature and Natural Resources 2001): CRB1ab(iii,v) + 2ab(iii,v); C2a(i); D.

Based on the study of living plants and herbarium specimens, the following couplet distinguishing $P$. balophilum from $P$. confertiflorum was produced. It is intended to supplement the existing key to Hawaiian Pittosporum by Wagner et al. (1990) by replacing the second couplet of no. 11 of that key.

\section{Key Couplet to Distinguish Pittosporum halophilum from P. confertiflorum}

11. Leaves moderately rugose, lower surface densely to moderately tomentose; capsules 20-35 mm long (even longer in cultivated material), apex rounded to obtuse; flowers terminal, axillary, or cauline (12).

12(11). Shrubs, $0.4-1.75 \mathrm{~m}$ tall, branches gray to medium brown; leaves $3.5-7.0 \mathrm{~cm}$ long, lateral veins 5-9 pairs, lower surface densely tan to golden yellow tomentose, base cuneate, petioles $0.2-1.2 \mathrm{~cm}$ long; capsules subcuboid to ovoid, densely tan to golden brown tomentose; flowers in most cases functionally unisexual

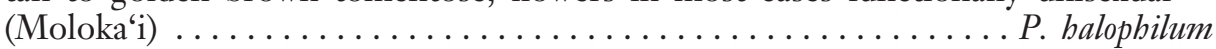

12. Shrubs or trees 2-9 $\mathrm{m}$ tall, branches dark brown to red brown; leaves $7-30 \mathrm{~cm}$ long, lateral veins 9-22 pairs, lower surface densely or moderately brown to reddish brown tomentose, base attenuate, petioles $1-5.5 \mathrm{~cm}$ long; capsules ovoid to broadly ovoid, densely brown to reddish brown tomentose; flowers perfect or unisexual (O'ahu, Lāna'i, Maui, Hawai'i) ............... 2. P. confertiflorum

Note: Using this key couplet, a population of Pittosporum confertiflorum from O'ahu (Hawai'i Loa Ridge) could key out to P. halophilum. However, that population does not occur in the salt spray zone and, according to molecular data (ISSR studies), groups with P. confertiflorum (C. Hogne-Beattie and C. Gemmill, unpubl. data).

\section{DISCUSSION}

\section{Dispersal Ability and Breeding Systems of} Pittosporum halophilum

Fruiting structures of Pittosporum are quite viscid and retain good dispersibility. Rock (1913) noted that the Hawaiian crow (Corvus hawaiiensis or 'alalā) would seek Pittosporum seed (Figure 3), and it is plausible that some forest birds may, during feeding, carry seeds into new localities (Carlquist 1966). Although native forest birds are rarely, if ever, seen around coastal sites at this point in time, Hawaiian offshore islets are still one of the few remaining refugia for seabirds (Duvall 1999, Wood 2001). Perhaps this is directly related to the relictual presence of $P$. balophilum on these islets.

Further research is needed to better understand the breeding system of Hawaiian Pittosporum, including P. balophilum. The fragrant pale white or cream-colored flowers of $\mathrm{Ha}$ waiian Pittosporum and their coherent corollas 


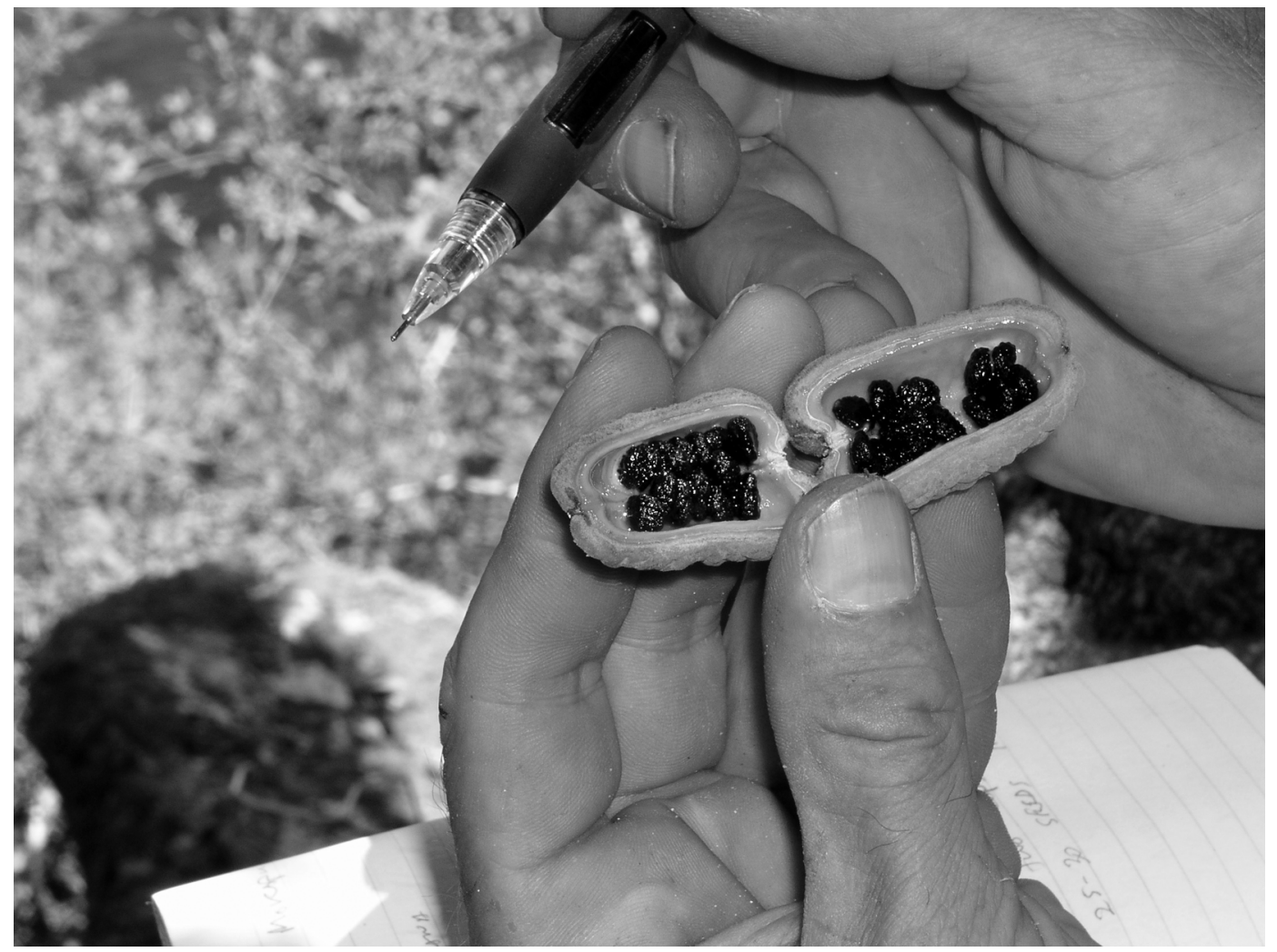

Figure 3. Pittosporum halophilum capsule with seeds.

forming a tube at anthesis (Figure 4) are indicative of moth pollination. Swezey (1954) was aware of several orders of insects associated with Pittosporum and made reference to a few moth genera including species of Hyposmocoma, Diplosara, and Parectopa (Lepidoptera). Steven L. Montgomery (2007, pers. comm.) noted additional species of Hyposmocoma and Philodoria (Lepidoptera) that are associated with Pittosporum along with several species of Plagithmysus (Coleoptera), Sarona (Heteroptera), and Drosophila (Diptera). Currently, herbarium vouchers and cultivated individuals indicate that $P$. balophilum is, with very few exceptions, functionally unisexual, having separate male and female plants. Yet the only two female individuals at Huelo produced viable seeds in the absence of male plants on the islet, and the isolated plant at the Küka'iwa'a site continues to produce viable seeds. Possible explanations are the occasional occurrence of hermaphroditic flowers on individuals that are otherwise functionally unisexual (rarely observed in cultivation) or apomictic seed production. Also a pollinator up to now unobserved could make floral visitations between Moloka'i and the adjacent islets.

Because many insular endemic plants have coevolved with endemic insects and require each other for survival, it is important to encourage further investigations into the natural life cycles and breeding systems of Pittosporum halophilum. Embryological studies and flower bagging experiments on the cultivated material might contribute to a better understanding of the reproductive biology of this highly endangered species. 


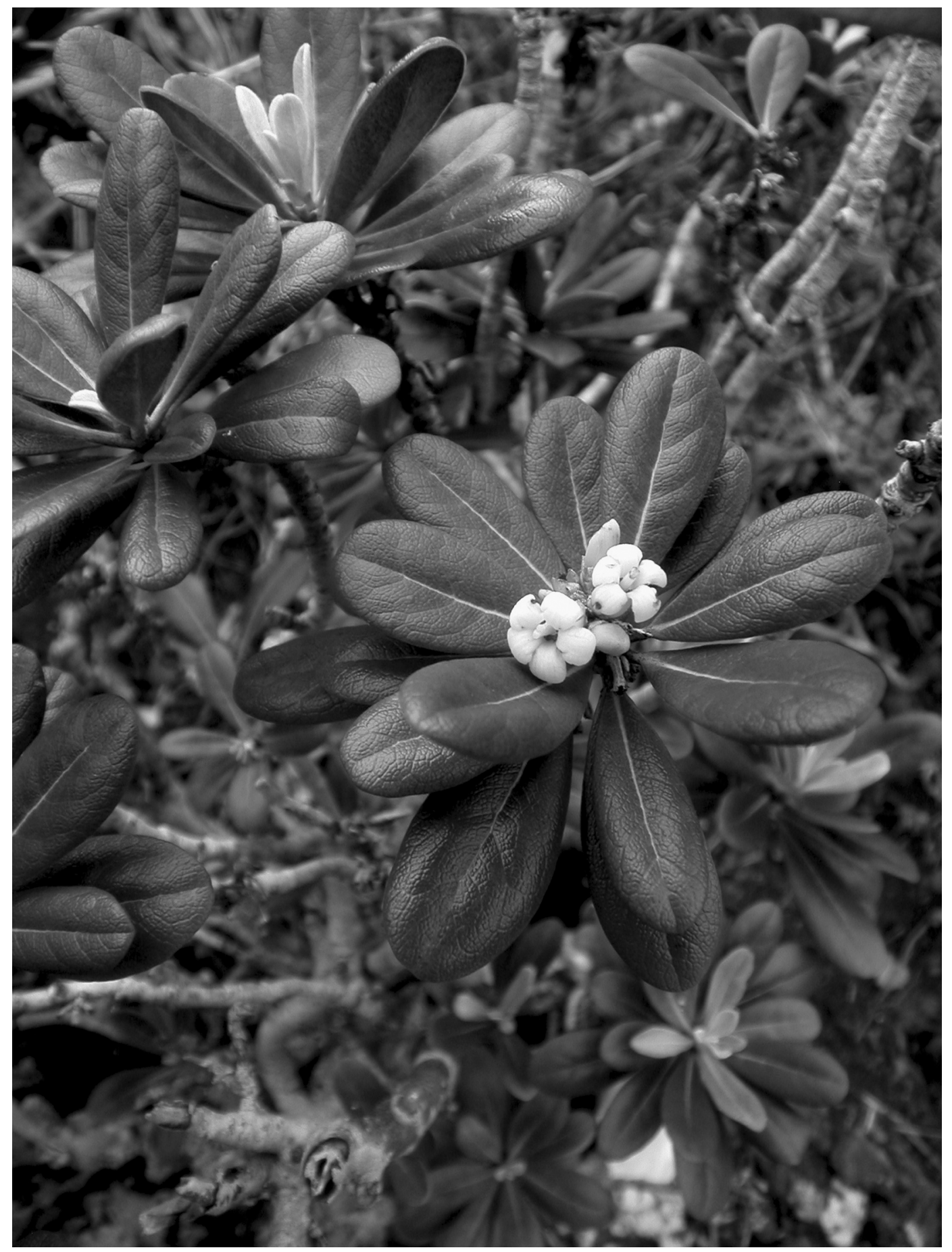

FIgURE 4. Pittosporum halophilum in flower (pistillate individual). 
Threats to the Habitat of Pittosporum halophilum

The likelihood of extinction for the remaining wild colonies of Pittosporum halophilum seems to be considerably high over the next 10 yr. Several factors that are threatening many of Hawai'i's rare taxa have also put $P$. balophilum into the critically endangered category. These threats include (1) catastrophic extinction through environmental events, especially severe erosion and landslides (Table 1); (2) competition with nonnative plant taxa, especially Lantana camara L., Pluchea carolinensis (Jacq.) G. Don, Psidium guajava L., Schinus terebinthifolius Raddi, Clidemia birta (L.) D. Don, and Kalanchoe pinnatum (Lam.) Pers. (Smith 1985), all of which are present in the distribution area of $P$. halophilum (Wood 2008); (3) reduced reproductive vigor as the result of limited numbers of surviving individuals (Center for Plant Conservation 1991, Neel and Cummings 2003); and (4) ecosystem degradation at Kūka'iwa'a by nonnative feral goat (Capra hircus L.), axis deer (Axis axis Erxleben), and pig (Sus scrofa L.), and predation of seed by rats (Rattus sp.) (Janzen 1971, LeGrande 2002, Marshall et al. 2008).

\section{Conservation Status of Pittosporum halophilum}

The rediscovery of Pittosporum halophilum individuals on Moloka'i and several of its adjacent islets has launched a series of conservation efforts to protect its habitat and to prevent extinction of the species. During February 2008, rodenticide pellets were aerially applied by helicopter to Mōkapu on two separate occasions, and since those applications no rats have been observed on the islet. Subsequently, a single new seedling of $P$. halophilum was observed at the northeastern end of the islet (Wood 2010). The ability of the species to thrive in sea spray, along with its strikingly vigorous and pleasing appearance, has made $P$. halophilum a prime choice for coastal restoration projects within Moloka'i's National Park.

To promote long-term survival of $P$. balophilum, efforts have been made to con- serve diversity at several discrete levels, including subpopulations, individuals, and alleles. Since the 1994 rediscovery of the species, 28 conservation collections of seed and/or cuttings have been made from wild source material (Table 1). Thirteen of the 20 known in situ individuals, representing all four subpopulations, have been grown in cultivation from seed collections, and in one instance cloned material from cuttings has been successfully cultivated from an in situ staminate individual. Unfortunately, 12 in situ individuals of $P$. balophilum have died over the last $16 \mathrm{yr}$ from landslides and/or prolonged dry periods. Six of these in situ individuals that have perished have been successfully propagated ex situ, but the remaining six, including three staminate, two pistillate, and a single individual of unknown sex have gone unrepresented in cultivation.

About 150+ individuals are currently being cultivated ex situ at the NTBG, the KNHP, and the Lyon Arboretum (O'ahu, Hawai'i). In addition, the KNHP is restoring coastal habitat within portions of its fenced Kūka'iwa'a Peninsula property. This restoration project includes outplantings of common coastal species along with other rare plant taxa such as Pritchardia hillebrandii (Kuntze) Becc., Scaevola coriacea Nutt., and Brighamia rockii $\mathrm{H}$. St. John. The overall plant community is being modeled after the existing Pritchardia billebrandii coastal forest on Huelo (LeGrande 2002). Without such combined ex situ/in situ efforts, Pittosporum halophilum would likely go extinct in the very near future.

\section{ACKNOWLEDGMENTS}

We are grateful to Dave Boynton, Fern Duvall, James Espaniola, Chrissen E. C. Gemmill, Guy Hughes, Maya LeGrande, Hank Oppenheimer, and Steve Perlman, who assisted during field research. For discussions on Hawaiian Pittosporum we thank C. Gemmill, Joel Lau, David H. Lorence, Steven L. Montgomery, and H. Oppenheimer. Thanks are due to Warren L. Wagner and two anonymous reviewers for valuable comments. C. Gemmill and C. Hogne-Beattie are thanked for providing unpublished molecular data. C. 
Gemmill also critically checked the discussion of the molecular findings. We thank the horticulturalists at NTBG, Lyon Arboretum, and KNHP who have grown P. balophilum and include a special recognition to Guy Hughes, Wildlife Biologist, KNHP; Chris Swenson, Pacific Region Coordinator, USFWS Coastal Program; and David Burney, Conservation Chair, NTBG, for their leading efforts in coastal and islet conservation/restoration. The herbarium BISH is thanked for providing an image of the lectotype specimen of Pittosporum halophilum. M.K. gratefully acknowledges support by the University of Vienna and the NTBG for his work on Kaua' $i$.

\section{Literature Cited}

Carlquist, S. 1966. The biota of long-distance dispersal. III. Loss of dispersibility in the Hawaiian flora. Brittonia 18:313-317.

- 1974. Island biology. University of Columbia Press, New York.

Carr, G. D. 1978. Chromosome numbers of Hawaiian flowering plants and the significance of cytology in selected taxa. Am. J. Bot. 65:236-242.

Cayzer, L. W., M. D. Crisp, and I. R. H. Telford. 2000. Revision of Pittosporum (Pittosporaceae) in Australia. Aust. Syst. Bot. 13:845-902.

Center for Plant Conservation. 1991. Genetic sampling guidelines for conservation collections of endangered plants. Pages 225238 in D. A. Falk and K. E. Holsinger, eds. Genetics and conservation of rare plants. Oxford University Press, New York.

Chandler, G. T., G. M. Plunkett, S. M. Pinney, L. W. Cayzer, and C. E. C. Gemmill. 2007. Molecular and morphological agreement in Pittosporaceae: Phylogenetic analysis with nuclear ITS and plastid trnL-trnF sequence data. Aust. Syst. Bot. 20:390401.

Duvall, F. 1999. Observations on Huelo Islet, Moloka'i, including checklist of land vertebrates. Hawai'i Department of Land and Natural Resources, Division of Forestry and Wildlife, Honolulu.

Fosberg, F. R. 1948. Derivation of the flora of the Hawaiian Islands. Pages 107-119 in E. C. Zimmerman, Insects of Hawai'i. Vol. 1. University of Hawai'i Press, Honolulu.

Gemmill, C. E. C., G. J. Allan, W. L. Wagner, and E. A. Zimmer. 2002. Evolution of insular Pacific Pittosporum (Pittosporaceae): Origin of the Hawaiian radiation. Mol. Phylogenet. Evol. 22:31-42.

Haas, J. E. 1977. The Pacific species of Pittosporum Banks ex Gaertn. (Pittosporaceae). Allertonia 1:73-167.

International Union for Conservation of $\mathrm{Na}$ ture and Natural Resources (IUCN). 2001. IUCN Red list categories and criteria. Version 3.1 (http://www.iucn.org). IUCN, Gland, Switzerland, and Cambridge, United Kingdom.

Janzen, D. H. 1971. Seed predation by animals. Annu. Rev. Ecol. Syst. 2:465-492.

Kiehn, M. 2005: Chromosome numbers of Hawaiian angiosperms: New records and comments. Pac. Sci. 59:363-377.

LeGrande, M. 2002. Survey of Kūka'iwa'a Peninsula, Kalaupapa National Historical Park (KNHP), Moloka'i, Hawai'i. Botanical report prepared for and available from KNHP.

Marshall, S. M., G. D. Hughes, and K. Kozar. 2008. Small, non-native mammal inventory in Kalaupapa National Historical Park. Pacific Cooperative Studies Unit, University of Hawai'i at Mānoa, Technical Report 158.

Neel, M. C., and M. P. Cummings. 2003. Effectiveness of conservation targets in capturing genetic diversity. Conserv. Biol. 17:219-229.

Rakoczy-Trojanskowska, M. 2004: Characteristics and a comparison of three classes of microsatellite-based markers and their application in plants. Cell. Mol. Biol. Lett. 9:221-238.

Rock, J. F. 1911. Notes upon Hawaiian plants with descriptions of new species and varieties. Coll. Hawaii Publ. Bull. 1:1-20.

- 1913. The indigenous trees of the Hawaiian Islands. Publ. privately, Honolulu. Reprinted with introduction by $\mathrm{S}$. Carlquist and addendum by D. R. Herbst, 1974, Charles E. Tuttle Co., Rutland, Vermont. 
Sherff, E. E. 1941. New or otherwise noteworthy plants from the Hawaiian Islands. Am. J. Bot. 28:18-31.

. 1942. Revision of the Hawaiian members of the genus Pittosporum Banks. Field Mus. Nat. Hist. Publ. Bot. Ser. 22 467-566, 574-580.

Smith, C. W. 1985. Impact of alien plants on Hawai'i's naïve biota. Pages 180-250 in C. P. Stone and J. M. Scott, eds. Hawai'i's terrestrial ecosystems: Preservation and management. University of Hawai'i Cooperative National Park Resources Studies Unit. University of Hawai'i Press, Honolulu.

Swezey, O. H. 1954. Forest entomology in Hawaii: An annotated check-list of the insect faunas of the various components of the Hawaiian forests. Bernice P. Bishop Mus. Spec. Publ. 44.

U.S. Fish and Wildlife Service. 2010. Endangered and threatened wildlife and plants: Determination of endangered status for 48 species on Kaua' $i$ and designation of critical habitat; Final rule. Fed. Reg. 75:1896019165.

Wagner, W. L., M. Bruegmann, D. R. Herbst, and J. Q. Lau. 1999. Hawaiian vascular plants at risk: 1999. Bishop Mus. Occas. Pap. 60:1-64.

Wagner, W. L., and D. R. Herbst. 1999. Supplement to the Manual of the flowering plants of Hawai'i. Pages 1855-1918 in W. L. Wagner, D. R. Herbst, and S. H. Sohmer, Manual of the flowering plants of Hawai'i, revised ed. 2 vols. University of Hawai'i Press, Bishop Museum Spec. Publ. 97, Honolulu.

Wagner, W. L., D. R. Herbst, and S. H. Sohmer. 1990. Manual of the flowering plants of Hawai'i. 2 vols. University of Hawai'i Press, Bernice P. Bishop Museum Spec. Publ. 83, Honolulu.

Wood, K. R. 2001. Pritchardia coastal forest on Huelo Islet, Moloka'i, Hawai'i. Biological report prepared for and available from Kalaupapa National Historical Park. 2008. Vegetation descriptions of Kūka'iwa'a Peninsula and the three islets of Huelo, Mōkapu and 'Ōkala, Moloka'i, Hawai'i. Special report prepared for and available from Kalaupapa National Historic Park, Kalaupapa, Hawai'i.

. 2010. Notes on the flora of Mōkapu Islet, Moloka'i, Hawaiian Islands. Report prepared for the Kalaupapa National Historical Park (KNHP) and the Offshore Islet Restoration Committee (OIRC). Available from KNHP.

Wood, K. R., and M. LeGrande. 2002. Biological notes of two survey trips to Huelo Islet, Moloka'i, Hawai'i. Report prepared for and available from the Kalaupapa $\mathrm{Na}$ tional Historical Park (KNHP). 